\title{
The Architecture of Project-Based Learning in the Supplementary Vocational Education System in a Higher Education
}

\author{
https://doi.org/10.3991/ijet.v15i04.11694 \\ Vladislav Lizunkov ${ }^{\left({ }^{凶}\right)}$, Ekaterina Politsinskaya, Konstantin Gazin \\ Tomsk Polytechnic University, Kemerovo Oblast, Russia \\ vladeslave@rambler.ru
}

\begin{abstract}
The article deals with the organization of project-based education applied in the supplementary higher vocational education system and considers the needs of modern society in the context of creating a Priority Development Area. (PDA). In the article, the authors present the architecture of the integrated model of traditional and project-based learning in the supplementary vocational education system, offer practical recommendations on the organization and implementation of project activities in the staff training demanded in PDA. The article reflects the results of introducing the integrated model of traditional and project-based learning in the supplementary vocational education system.
\end{abstract}

Keywords - PDA, supplementary vocational education, training, retraining, the architecture of the integrated model of traditional and project-based learning, in-demand staff.

\section{Introduction}

The supplementary vocational education is an important element of educational activity. In the modern world, its role has especially increased due to the sharp acceleration of scientific and technological progress, since the acquired knowledge is rapidly becoming obsolete, and the number of new ones is rapidly increasing. The new directions appear, for example, nanotechnology, existing professions become more complicated, the staff is dynamically redistributed. The supplementary vocational education turns into a separate area of education, the volume of which is growing significantly.

In globalizing world economy, the creation of priority development areas is one of the effective tools conducive to the development of production and building foreign economic relations. The creation of priority development areas is a common practice for countries seeking to attract not only national but also foreign investors to develop their national economies [1].

On December 29, 2014, Federal Law "On the territories of advanced socioeconomic development in the Russian Federation" was adopted and has introduced 
into the legal fold a new type of preferential territories - PDA. PDA is not just a status, it is a certain amount of conditional economic freedom officially granted by the Russian government for quick, serious and effective work aimed at strengthening the state's economy. Higher educational institutions face the challenge of providing not only full-fledged professional staff training but also retraining existing specialists in a short time for sustainable and stable economic growth, bringing domestic high-tech products to the world market, strengthening the international authority and defence capability of Russia [2;3]. The shortage of engineering staff is a factor limiting the development of the country's industry [4].

Implementation of supplementary vocational education programs has its forms and features. The duration of training can range from 6 to 1000 academic hours or more, students are focused on considering specific situations, the latest scientific and technical advances. It follows that the educational process in the supplementary vocational education system should be organized according to certain technologies tailored to an adult professional audience. The relevant professional standards should guide supplementary vocational education programs. All this implies special requirements for the educational and methodological documentation, the educational process, etc.

Another important task of the supplementary higher vocational education includes training students through professional programs focused on the performance of specific labour functions required by the customer or to pass an exam for a professional certificate.

The idea of supplementary higher vocational education of students is quite new in comparison with the traditional system of specialists retraining and has its specific features.

\section{Subject and Methods of Research}

Our analysis of bachelors training level, according to residents of PDA and PDA`s employers, allows us to conclude that they are unanimous in their opinion that "bachelors need further training." The introduction of an additional amount of practical knowledge and skills into the educational process under the main educational program will allow students to pass the exam for compliance with the professional standard during the training process and to continue to perform official duties in organizations, enterprises, with a minimum adaptation time. Getting additional qualifications by students will expand employment opportunities for graduates due to the rapidly changing labour market conditions. It results in the need to obtain practical skills in specific areas, specializations, allowing graduates to assume professional duties with a minimum of "retraining" time.

Bachelors can undertake a specific program of practical orientation with the business requirements of the region. These can be highly professional or functional intersectoral programs in-demand in a given period. Such programs can be drawn up at the request of specific employers, specifying the required competencies and the degree of their development. 
Thus, the competent and massive implementation of the vocational professional education system compensates to a large extent for the disadvantages of shortened professional training in bachelor's degree programs. Such retraining has many advantages compared to the master's degree program, which is academic and carried out according to sustainable programs with a small variability degree.

Another focus of professional retraining programs is the retraining of specialists with higher education who have received a certain qualification a long time ago, and therefore it has ceased to be in demand on the labour market. Thus, there is a need for specialists retraining in new demanded activities.

In the vocational education system, the student pays attention not only to knowledge, skills, but also the methodology for their implementation, new methods and techniques, quality, teacher competence, and training intensity.

One of the conditions for organizing high-quality supplementary education is project-based learning.

\subsection{The architecture of the integrated model of traditional and project-based learning}

The project-based learning involves an educational approach, in which students develop a practical solution to the urgent problems of various economic and social sectors, use interdisciplinary relationships, collaborate among themselves and with external participants, receive advice from the project curator and achieve a real result.

The project-based method has a long history and extensive experience in various countries. For example, a number of educational programs of European universities are based on project-oriented education, focused on developing teamwork, negotiation, communication skills, etc. [5-12]. For example, in the USA, they actively use the project-based method in universities to establish links between education and the market.

Many modern Russian teaching researchers, for example, Safonova K.I., Podolsky S.V., Pyankova L.A., Khomicheva V.E., Neprokina I.V., Ryskulova M.N. et al. [1316] consider the project-based method one of the effective ways to develop students professional competencies.

Nevertheless, project activity should not replace substantive systematic education but be used along with it as a component of the education system. The task of projectbased learning is to complement traditional education and bring it closer to economic sectors and their needs, with real professional practice.

Figure 1 presents the integrated model of traditional and project-based learning in the supplementary vocational education system 


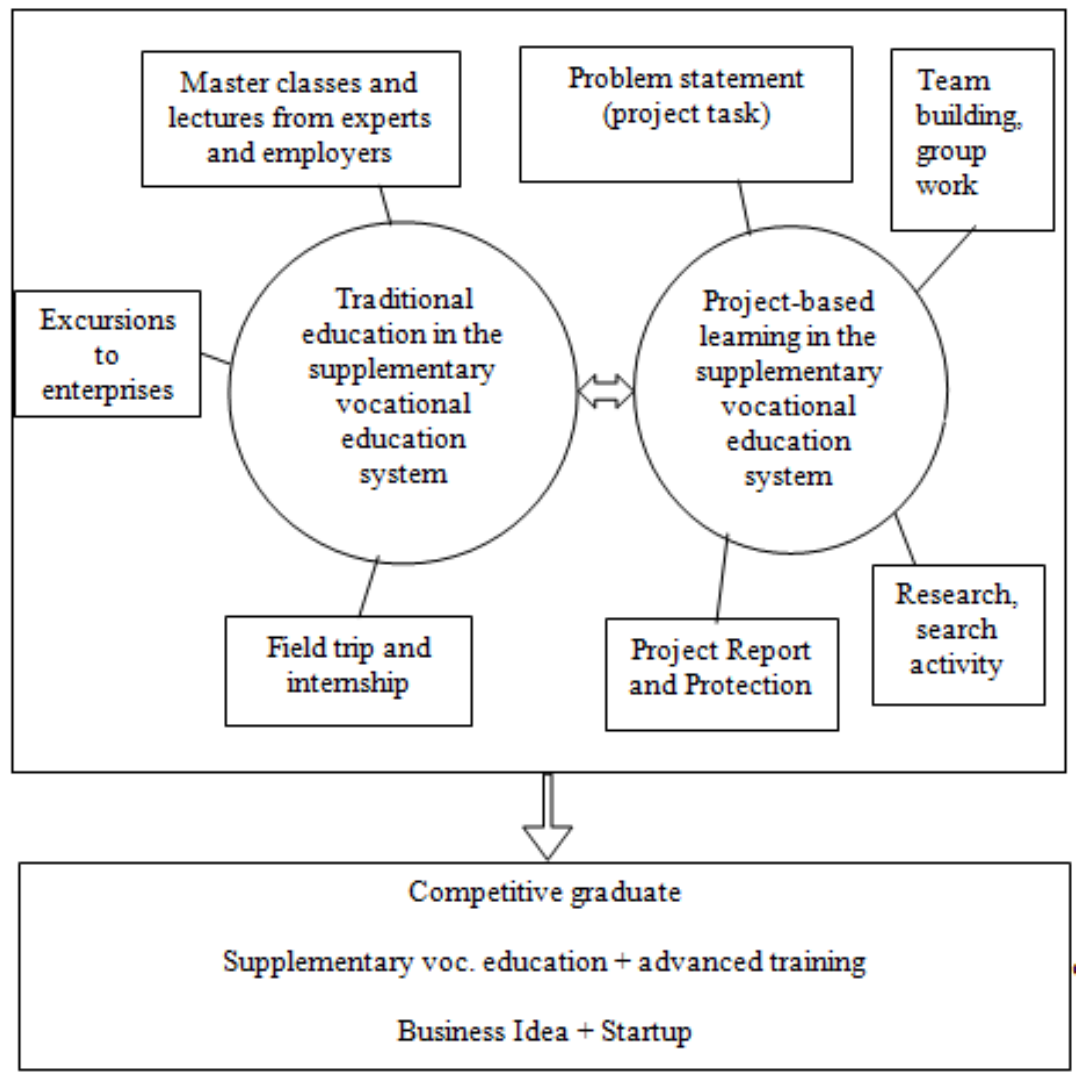

Fig. 1. The integrated model of traditional and project-based learning in the supplementary vocational education system

Currently, the project-based method is applied at all levels of education. However, we believe that its positive aspects remain underutilized in the supplementary vocational education system.

The main idea of implementing practice of project-based learning in supplementary vocational education is in a special organization form of independent, individual or group work of students [17]. The process of students' interaction should take place in project classrooms, which are an open space for 10-12 groups simultaneously.

\subsection{Requirements for the organization of project activities}

When forming the students' group it is necessary to adhere to the following recommendations:

- The group size should be between 3 and 7 people depending on the objective of the project and the tasks to be determined for the group. An excessive number of group 
members can lead to difficulties in distributing the share of responsibility in achieving this goal.

- Do not stick to the permanent group composition since a young specialist, searching for a permanent job on the labour market, finds himself in various social relations and have to adapt to them. The periodically changing group composition forms the ability of students to find a common language in a new environment, the ability to work in a team.

- When choosing a team leader, each student has, preferably, shown itself in this function. This develops organizational competence, a necessary component of the professional competence of a modern specialist.

- Both the teacher and the group members can distribute tasks among the group members. At the same time, roles are distributed, individual tasks are formed, and responsible executors for individual tasks are appointed.

- If group work takes place in an auditorium, then it requires special preparation. Students should so sit as they can see each other and communicate without disturbing the participants of another group. The teacher could easily move from one group to another.

A positive result of this learning approach is possible if the following conditions are met:

- It is necessary to distribute the work on the project so its implementation involves equally all group members. The feeling that the overall result depends on you is a strong motive in project activities.

- The project should be feasible and consistent with the capabilities and abilities of supplementary vocational education students.

- It is desirable to have competition between groups. Groups can get the same projects and compete in several categories: the most unexpected solution, effective presentation, the most accessible method of presentation, etc.

- The curator must explain in detail the assessment of their work to the group. He should explain the purpose and tasks assigned to the group. Group work is more successful when students know in advance clear criteria for evaluating work.

Students receive the necessary infrastructure for the project: workplaces at the university, equipment, computing power, etc, a project work schedule and a project curator from among the teachers.

External experts and consultants are invited from among representatives of organizations, residents of PDA who are interested in the results of individual projects, training and staff retraining [18].

\section{Survey Results Analysis}

The National Research Tomsk Polytechnic University is actively developing project activities. At the beginning of the school year, the Institute's departments form a portfolio of projects by calling for project initiatives. The institute, teachers or an 
external customer, for example, an enterprise, can act as a project employer. Currently, projects by PDA resident enterprises predominate.

From 2016 to 2019, more than 1000 students were trained under the integrated model of vocational professional education. The surveys of PDA employers, students, teachers and curators of project activities were conducted to analyze the effectiveness of the integrated model of traditional and project-based learning.

A survey of PDA employers on the quality of training for supplementary vocational programme students and graduates revealed an increase in satisfaction with such indicators as: willingness to practice, the formation of basic skills, the ability to work in a team, the ability to professional communications.

The analysis of student profiles confirmed that students of continuing education programs prefer project-based forms of learning, finding them more interesting in contrast to traditional learning forms. The graduates questionnaires note that, entering the labour market, they clearly understand the nature of their professional activities, what they will do after graduation.

Project curators and teachers note an increase in motivation for study, for engineering, new technologies, and a desire for professional growth [19].

\section{Conclusion}

Thus, the implementation of project training in the system of supplementary vocational education will allow students to gain experience:

- Solving real problems from their future or current professional activities;

- Real research, design

- Team work

- Meeting deadlines

- Responsibility for the result

Thus, the National Research Tomsk Polytechnic University builds the architecture of project-based learning, according to which students of supplementary vocational education programs participate in real professional activities. After completing educational courses or professional retraining, they can work in companies, which they have already developed relationships with while working on other projects, or advance individual rationalization proposals at the enterprise in the framework of their regular professional activities.

\section{Acknowledgement}

"The article was carried out with the financial grant support of the Russian Science Foundation (project No. 19-78-00018)". 


\section{$6 \quad$ Referenses}

[1] Filatova M.Yu. Study of the evolution of scientific views on international labour migration //News of Tula State University. economic and legal sciences, No. 4 (1), Pp. 216-222. 2015.

[2] Bondarenko O.V, Oliferova O.S. Staffing policy at industrial enterprises as a tool for regulating the labour market's structural imbalance // Scientific notes of Komsomolsk-onAmur State Technical University. Ser .: The science of human, society, culture, No. IV-2 (24), Pp. 87-91. 2015.

[3] Larionov A.O. Evaluation of the industrial potential of the region // Problems of the development of the territory, No. 2 (76). 2015. URL: https://cyberleninka.ru/article/n/otsenka-promyshlennogopotentsiala (date of reference: 30.04.2018).

[4] Demikhov K.E. Engineering Education: state, problems, prospects // Outlines of global transformations: politics, economics, law, No. 2. 2009. URL: https://cyberleninka.ru/ article/n/inzhenernoe-obrazovanie-sostoyanie-problemy-perspektivy (date of reference: 30.04.2018).

[5] Hämeen-Anttila K., Saano S., Vainio K. Professional competencies learned through working on a medication education project // American Journal of Pharmaceutical Education, Vol. 74, Issue 6, P. 1-8. 2010. https://doi.org/10.5688/aj7406110

[6] Queiroz-Neto J. P. Using modern pedagogical tools to improve learning in technological contents // Proceedings of Frontiers in Education Conference, FIE. P. 1-8. 2015. https://doi.org/10.1109/fie.2015.7344383

[7] Ginestié J. The Industrial Project Method in French Industry and in French Schools // International Journal of Technology and Design Education, vol.12, issue 2, pp. 99-122. 2002. https://doi.org/10.1023/a:1015213511549

[8] By Mo, John P.T.; Tang, Y.M. Project-based learning of systems engineering V model with the support of 3D printing // Australasian Journal of Engineering Education, vol.22, issue 1, pp. 3-13. 2017. https://doi.org/10.1080/22054952.2017.1338229

[9] Pounds P. E. I. Teaching mechatronics with tuned problem-based projects // Australasian Journal of Engineering Education, vol. 20, Issue 1, pp. 41-58. 2015. https://doi.org/10.71 $\underline{58 / \mathrm{d} 14-002.2015 .20 .1}$

[10] Palmer S., Hall W. An evaluation of a project-based learning initiative in engineering education // European Journal of Engineering Education, vol. 36, issue 4, pp. 357-365, 2011. https://doi.org/10.1080/03043797.2011.593095

[11] Xu Y. Liu W. A project-based learning approach: a case study in China // Asia Pacific Education Review, vol. 1, issue 3, pp. 363-370, 2010. https://doi.org/10.1007/s12564-0109093-1

[12] Du X. Su L., Liu J. Developing sustainability curricula using the PBL method in a Chinese context // Journal of Cleaner Production, vol. 61, pp.80-88. 2013. https://doi.org/10.1016/j. jclepro.2013.01.012

[13] Safonova K.I., Podolsky S.V. Project activities of students in a higher educational institution: project planning and impact assessment // Society: Sociology, Psychology, Pedagogy, No. 5, pp. 83-94. 2018. https: //doi.org/10.24158/spp.2018.5.16.

[14] Pyankova L. A., Khomicheva V. E. Project activities at the university as a condition for the formation of motivation and value component of professional self-determination of students of a technical university // Society: Sociology, Psychology, Pedagogy, No. 3, Pp. 86-90. 2019. Https: //doi.org/10.24158/spp.2019.3.14. 
[15] Neprokina I.V. Design as a trend of the modern learning system // Society: Sociology, Psychology, Pedagogy, No. 4, P. 90-93. 2018. https://doi.org/10.24158/spp.2018.4.16.

[16] Ryskulova M.N. The teamwork skills development among engineering students // Society: Sociology, Psychology, Pedagogy, No. 12, Pp. 229-233. 2018. https://doi.org/10.24158/ spp.2018.12.39

[17] Pooya Taheri Project-Based Approach in a First-Year Engineering Course to Promote Project Management and Sustainability // International Journal of Engineering Pedagogy (iJEP), vol 8, no 5, pp.11-12. 2018. https://doi.org/10.3991/ijep.v8i3.8573.

[18] Politsinskaya, E., Lizunkov, V., Ergunova, O. Organization of student project based activities through individual learning routes // International Journal of Emerging Technologies in Learning, vol 14, Issue 11, 2019, pp. 186-193. https://doi.org/10.3 991/ijet.v14i11.10312.

[19] Maulana, I.T., Hary, R.D.,Purwasih, R., Firdian, F., Sundara, T.A., Na'am, J. Project-based learning model practicality on local network devices installation subject // International Journal of Emerging Technologies in Learning, vol 14, Issue 15, 2019, pp. 94-106. https://doi.org/10.3991/ijet.v14i15.10305.

\section{$7 \quad$ Authors}

Vladislav Lizunkov, PhD, Tomsk Polytechnic University Yurga Institute of Technology, Russia, vladeslave@rambler.ru. The area of scientific interests is the theory and methodology of vocational training.

Ekaterina Politsinskaya, undergraduate, Tomsk Polytechnic University, Russia, Katy031983@mail.ru. The area of scientific interests is the theory and methodology of vocational training.

Konstantin Gazin, student, Tomsk Polytechnic University Yurga Institute of Technology, Russia, gazin89@mail.ru. The area of scientific interests is the theory and methodology of vocational training.

Article submitted 2019-09-17. Resubmitted 2019-11-13. Final acceptance 2019-11-18. Final version published as submitted by the authors. 